\section{Contribuições para - estudo dos meios de comunicação}

\section{RESUMO}

Partindo da tentativa de situar os estudos dos meios de comunicação em relação às principais correntes teóricas da comunicação de massa, o texto desenvolve um estudo da definição do conceito e dos planos de análise dos meios de comunicação. Na primeira parte é exposto um rápido panorama dos estudos de comunicação, onde se constata a lacuna dos estudos de meios. A segunda parte é constituída por uma proposta de conceituação e estudo dos meios.

\section{ABSTRACT}

This text is a study both on the definition and on the levels of analysis of the media of communication. It first shows that there are very few references on the subject. Afterwards, it proposes a conceptual model for the definition and the study of those media.

\section{palavras-chaVe (KEY WORDS)}

- Teorias da comunicação (Communication theories)

- Tecnologias (Technologies)

- Meios (Media)

\section{Luiz C. Martino}

Professor da Universidade de Brasília (UnB)
"Após o dilúvio incessante das horas, uma nova ordem emergiu, deixando atrás de si, nas sombras do tempo, o mundo do Verbo. Neste novo começo, no princípio estava a Imprensa, depois veio o Rádio... e hoje o embaraço das possibilidades do futuro."

EIS ALGUMAS FRASES que poderiam servir de epígrafe para grande parte das atuais análises relativas à comunicação de massa. Esquecendo as condições de possibilidade deste novo mundo emergente, a seu modo elas contribuem para cavar um abismo em relação ao passado, elevando as conquistas tecnológicas a uma estatura magnífica e obsedante. É curioso notar que esta ruptura com a análise histórica da organização social é acompanhada de uma de antecipação do futuro. Sintoma claro de um desejo de esquecer o presente demasiado difícil de compreender. Desembaraçados da história, as análises se voltam para a especulação das novas possibilidades, se apressando em nos garantir que estas tecnologias serão a realidade de amanhã. Esta dogmática triunfante nos projeta na vertigem de uma espiral de inumeráveis possibilidades de mediações técnicas: o videofone, o cybersexo, a Internet, a "Super-Internet", a "maisque-super-Internet"... Mas o efeito mais curioso de uma tal "Gênese" do mundo na Era da Pós-Modernidade é sem dúvida a consolidação da especulação sobre as futuras possibilidades das novas tecnologias de comunicação, em detrimento do estudo dos meios reais e efetivamente presentes na vida social.

Penso que esta tendência das pesquisas pode ser explicada, em parte, pelo esgotamento do paradigma empírico-behaviorista (ou positivista), sem que tenha havido outros modelos de análise para o substituir. Na verdade, o paradigma expresso pela célebre questão-programa formulada por Lasswell - "quem diz o que, por qual canal, para quem e com qual efeito?"1 - sempre esteve sujeito a graves críticas, mas dois fatores foram decisivos para seu sucesso e longevidade: 
1) a necessidade de fornecer um status científico à pesquisa em comunicação;

2) a capacidade de organizar e dar unidade aos diversos aspectos da questão.

Precisemos que este paradigma desenvolveu sobretudo pesquisas no pólo do emissor (quem) e da mensagem (o que), pois a adoção do modelo positivista de ciência se mostra bem aquém da tarefa do estudo dos meios de comunicação. Precisemos, também, que as críticas que lhe foram dirigidas tiveram um curioso resultado, pois, sem poder superá-lo, elas não tiveram outra conseqüência salvo uma progressiva sobriedade no julgamento de seu alcance e, portanto, não puderam senão aperfeiçoar este paradigma. Ainda que outros modelos de ciência tenham sido adotados, eles não teriam sabido evitar uma desintegração da temática dos mass media em inumeráveis problemáticas isoladas e dispersas em diversas disciplinas científicas.

Nesta breve intervenção nós nos concentramos na elucidação deste aspecto do problema, e em algumas indicações para o estudo dos meios.

Comecemos então por observar que a unidade proporcionada pelo esquema de Lasswell repousa sobre a intencionalidade constitutiva do ato comunicativo. Quem diz alguma coisa exprime uma motivação qualquer, que em alguma medida está presente na Mensagem, a qual justifica a existência dos Canais, que enfim vai a submeter a outrem (para Quem), sempre com a intenção de produzir um Efeito, sobre este.

É evidente que o paradigma positivista se funda sobre o modelo da intencionalidade natural (quer dizer, aquela situada no nível do ato comunicativo ou aquela que um agente pode compreender em relação à ação de um outro agente), e que seria possível demonstrar que a evolução das pesquisas que adotaram este paradigma pode ser representada pelo deslocamento do centro da intencionalidade através dos diversos termos do esquema.

Abordemos uma análise de conjunto dos estudos da comunicação de massa. To- memos como referência, entre outros trabalhos, aquele de Jensen e Rosengren, ${ }^{2}$ para quem as tradições de pesquisa sobre os mass media poderiam ser esquematicamente classificadas em cinco grandes linhas de pesquisa, como segue.

1) As pesquisas sobre os Efeitos (no sentido estrito): o que os meios de comunicação fazem ao indivíduo?

2) As pesquisas sobre os Usos e Gratificações: o que o indivíduo faz dos meios de comunicação?

3) A Análise Literária: estudos que visam às estruturas das mensagens, quer dizer, que ficam ao nível das análises das obras veiculadas.

4) Os estudos sobre as Condições de Recepção: centrados sobre a análise que o público faz do conteúdo das mensagens.

5) As abordagens Culturalistas: que se afastam do meio de comunicação para levantar "questões teóricas e políticas".

Se examinarmos estas linhas de pesquisa poderemos verificar, como afirma Elihu Katz, que elas são em realidade desdobramentos dos estudos dos efeitos. Trata-se, como é sabido, do desenvolvimento do esquema de Lasswell (quem diz o que a quem com quais efeitos), ou de um aperfeiçoamento da idéia central deste paradigma. Com exceção da última, todas as outras tradições de pesquisa se concentram em um dos termos representados pelo esquema lasswelliano.

1) A pesquisa sobre os efeitos (no sentido estrito).

Logo de saída é preciso notar que as pesquisas sob esta rubrica privilegiam a questão da influência dos meios de comunicação no processo de formação da opinião pública. E isto de uma maneira muito particular, pois não se trata da formação no seu sentido mais amplo (educação informal, gênese histórica, estrutura social...), mas trata-se do poder dos meios de comunicação de influenciar as tomadas de posições do indivíduo (reforçando-as ou alterando-as) quando de um problema bem 
preciso. Por exemplo, a eleição de um presidente ou a influência da propaganda sobre um exército inimigo. Pode-se apontar o célebre trabalho de Lazarsfeld, Berelson e Gaudet, "The People Choice", e os trabalhos de Carl Hovland como os protótipos desse gênero.

Por mais que ampliemos o domínio de sua aplicação, esta tradição de pesquisa se funda sobre a influência do conteúdo das mensagens (informação) sobre os receptores e não sobre os meios de comunicação propriamente ditos. Seu centro de interesse é o estudo das reações do Receptor em função da Mensagem veiculada pelos meios de comunicação. Precisemos, ainda, que a Mensagem aqui deve ser compreendida como a intenção do Emissor, de modo que a comunicação é assimilada a uma relação de poder, onde o Emissor impõe sua vontade ao Receptor. Estes estudos se concentram sobre o sucesso desta empresa.

2) Já para a tradição de pesquisa sobre os Usos e Gratificações, o protótipo é certamente o estudo de Herta Herzog sobre as ouvintes das novelas de rádio.

Novamente, nós estamos diante de uma orientação centrada sobre a Mensagem e a reação do Receptor. Entretanto, desta vez a atenção se volta sobre o sentido efetivo que os usuários conferem aos conteúdos da mensagem e por conseguinte as gratificações que eles obtêm dessa forma de ocupação do tempo pessoal. Os termos "gratificação" e "uso" são tomados em um sentido solidário e reenviam à questão do reforçamento de uma prática a partir dos usos efetivos que as pessoas fazem da recepção de certos conteúdos veiculados. Se a motivação dos atores é levada em conta, sua análise permanece restrita, entretanto, ao domínio da relação entre o conteúdo da mensagem e a compreensão que os próprios atores têm de sua prática. De onde a inclinação psicológica deste tipo de abordagem que se ocupa das motivações individuais subjacentes à recepção e que investem o sujeito como Receptor.
3) A tradição da Análise Literária é sem dúvida a forma de abordagem mais antiga, visto que ela é uma extensão e uma adaptação dos estudos literários para a análise da comunicação de massa.

Como observam Jensen e Rosengren, do mesmo modo que os estudos sobre os Efeitos, "o sentido é considerado como imanente às estruturas do conteúdo". Estas duas linhas de pesquisa tomam a Mensagem como a intenção do Emissor, a diferença aparece na medida em que esta última interpreta a noção de mensagem de uma maneira mais ou menos restrita, seja como primado do código, seja como a intenção política ou ideológica (onde sua aplicação nas análises da propaganda). Fazendo abstração dos meios de comunicação, e procurando deduzir a reação dos Receptores a partir da estrutura ou do conteúdo do texto, é sobre o segmento da Mensagem, no seu sentido mais amplo, que recai então todas as atenções da tradição dos estudos literários.

4) Os Estudos de Recepção, assim como os Estudos dos Efeitos, retomam a relação Mensagem-Receptor desta vez para privilegiar este último termo.

Para esta linha de pesquisa as análises se concentram sobre a atividade de interpretação (decodificação) da mensagem. Trata-se então do estudo de uma atividade do sujeito, entendido aqui como Receptor de mensagens. Notemos, entretanto, que esta linha de pesquisa, não obstante a maior complexidade de sua elaboração teórica e as críticas que dirige à tradição do Estudo dos Efeitos, pode ser considerada como um caso particular desta última. Basta considerar o fato que a decodificação das mensagens, por mais pessoais que possam ser, não deixa de ser uma reação à mensagem. Sua característica maior é a ênfase sobre a atividade do sujeito no processo de decodificação.

5) Enfim a abordagem Culturalista. Sem dúvida a mais difícil de sintetizar. 
Esta dificuldade é perfeitamente compreensível dado que neste tipo de abordagem os meios de comunicação não podem ser expressos pelo esquema de Lasswell. E isto é bastante significativo. Trata-se da única perspectiva onde os meios de comunicação são considerados de forma a ultrapassarem os quadros do paradigma empiricista. Integrados à vida social, os meios de comunicação não podem ser representados de uma maneira simplificada.

A menos que se queira exprimir através de paradoxos, como aquele de McLuhan segundo o qual "o meio é a mensagem". O sucesso deste leitmotiv se deve em parte à sua novidade: trata-se de uma das primeiras tentativas de fundar o estudo dos meios de comunicação para além das divisões de um esquema analítico e de uma relação de oposição entre sociedade e meios de comunicação.

Infelizmente, McLuhan mesmo interpretou a superação desta posição dualista (meios de comunicação $e$ sociedade) como a determinação de uma instância sobre a outra, fazendo assim apenas uma renovação da posição anterior sem verdadeiramente realizar uma mudança mais profunda. Desta maneira, o estudo dos meios de comunicação torna-se um problema de equilíbrio delicado, sempre ameaçado pelo risco de submergir seu objeto na vida social, fazendo-os desaparecer sob as determinações de outras atividades mais significativas (economia, política, movimentos culturais, etc.); ou, ao contrário, de fazer da vida social uma determinação dos meios de comunicação (posição marcada por McLuhan).

Eis aqui, a grosso modo, as principais tradições de pesquisa nas quais se repartem os estudos sobre a comunicação de massa e nos quais os estudos sobre os meios de comunicação são normalmente subsumidos.

$\mathrm{Na}$ realidade, e não obstante toda a simplificação do panorama descrito acima, os meios de comunicação não constituem o objeto de nenhuma dessas linhas de pesquisa.

Bem entendido, nós não colocamos aqui em jogo a exatidão dos conhecimentos gerados por essas tradições de pesquisa, e longe de nós termos a pretensão de negar em bloco conhecimentos dos quais nós mesmos nos servimos.

Chamamos simplesmente a atenção sobre o fato que a pesquisa da comunicação de massa se constituiu historicamente sem privilegiar o estudo dos meios de comunicação. ${ }^{3}$

Com efeito, se a última das tradições aqui analisadas deixa entrever uma outra maneira de abordar a questão dos meios de comunicação, é preciso entretanto admitir que ela foi explorada no sentido de uma pesquisa dos efeitos dos meios de comunicação sobre a sociedade, sem todavia ter uma reflexão sobre esta relação, salvo aquela de uma causalidade primária sustentada pelo determinismo tecnológico.

Por outro lado, as quatro primeiras tradições se inscrevem diretamente no paradigma proposto por Lasswell, desmembrando o meio de comunicação em termos analíticos e em questões específicas. Elas reduzem a problemática a apenas um de seus aspectos para poder adaptá-la à abordagem analítica.

De qualquer forma, nós podemos constatar, analisando o conjunto das tradições de pesquisa que os meios de comunicação permanecem deslocados e mesmo marginais neste movimento que vai do micro ao macrouniverso da pesquisa, da analítica detalhada ao buraco negro da síntese absoluta.

Em suma, por mais incompleta ou polêmica que seja esta breve e certamente discutível visão de conjunto das tradições de pesquisa em comunicação de massa, não se colocara em questão, no entanto, o fato fundamental aqui para nós, que os estudos sobre os meios de comunicação se não foram sistematicamente negligenciados, ou preteridos, foram certamente deixados à margem das atenções dos pesquisadores. 


\section{Conceito de meios de comunicação}

De toda evidência, a atividade científica não pode se fundamentar sobre a polissemia dos vocábulos ordinários e o primeiro passo para a construção de seu objeto passa necessariamente pela construção desse objeto, visto que ele não deve ser confundido com a evidência empírica.

Ora, a importância da definição do conceito advém justamente da necessidade de recortar e selecionar de uma certa realidade empírica os seus traços mais significativos (no sentido de Max Weber). É através do conceito que nós limitamos e conseqüentemente definimos um objeto de estudo.

Mas se a necessidade das definições conceituais está longe de ser questionada pela comunidade científica, é de se estranhar que os meios de comunicação, na interface de tantas disciplinas das ciências humanas e sociais, não tenham sido alvo de uma discussão conceitual a altura da importância que lhes é consensualmente atribuída.

Encurralados entre a tautologia de definições sumárias e a desconsideração absoluta, a verdade é que a grande maioria dos trabalhos sobre meios de comunicação discorre diretamente sobre a matéria sem se ocupar em definir o que é uma TV, um rádio ou os meios de comunicação em geral. Normalmente o sentido particular que cada trabalho imprime ao termo se explicita ao longo de sua exposição, sendo que três sentidos implícitos perfazem quase a totalidade das acepções em jogo. Elas colocam três planos diferentes para a análise :

1) O plano da acepção tecnicista, ou técnica no sentido dos engenheiros. Os meios de comunicação aparecem como sinônimo de suporte físico, o qual implica estudos que envolvem os conhecimentos das ciências exatas ou naturais, tais como os da mecânica ou da eletrônica.

2) O plano das instituições, que os meios de comunicação mais complexos colocam em jogo na medida em que constitu- em uma verdadeira cadeia de produção envolvendo a divisão do trabalho. É o plano mais geral da gestão/elaboração da informação, para o qual confluem a atividade dos jornalistas, o de diretores de produção, organizadores de programação, artistas...

3) Finalmente, o plano do eletrodoméstico, do aparelho, compreendendo por esta expressão não o produto da cadeia técnica (o que significaria apenas a repetição do primeiro nível), mas justamente a interface entre um dispositivo técnico e o utilizador humano.

\section{Plano tecnicista}

Não é difícil de perceber que as questões técnicas enquanto estritamente técnicas, quer dizer, na acepção restrita do engenheiro, não possuem, para nós, senão um interesse marginal. Além do mais, um meio de comunicação, ao contrário do que se poderia crer, não representa nenhuma forma técnica específica. A escrita, por exemplo, designa a sinergia de uma pluralidade de técnicas: fabricação de um suporte (tabletes de argila, papiros, papel...); invenção e estabelecimento de um sistema de convenções (desenhos geométricos ou figurativos, ideogramas, alfabeto silábico...); instituições de aprendizagem das regras de codificação da mensagem (procedimentos mnemotécnicos, rituais, templos, mosteiros, escola laica...). Esta observação é igualmente válida para o telégrafo (óptico, elétrico, "à cadran", sem fio...) ou para a fotografia (daguerreótipo, calotipo, Polaroid, suporte numérico...), ou ainda para qualquer outro meio de comunicação: a televisão, como qualquer outro meio de comunicação, não trocou de nome, e nem foi privada de sua identidade a cada aperfeiçoamento tecnológico.

A recusa de identificar os meios de Comunicação a dispositivos tecnológicos bem precisos permite de compreender que a técnica não se reduz aos objetos materiais, mas que se trata também de um processo infinito de criação e adaptação desses objetos. 
Assim, nós afastamos a possibilidade de definir os meios de comunicação por um de seus componentes técnicos, já que o progresso tecnológico nos oferece opções que vêm sistematicamente transformar os quadros dos aparatos tecnológicos estabelecidos.

Notemos também que não se trata de objetos técnicos quaisquer, mas trata-se de meios de comunicação. Por exemplo, a diferença entre uma conversação através de um víideofone, de uma teleconferência através de uma rede informatizada e a prática de um telespectador, é mais fácil de ser estabelecida levando-se em conta o tipo de comunicação (respectivamente: bipolar, multipolar reversível e de difusão a partir de um ponto) que se tomando a tecnologia envolvida.

Enfim, pela própria natureza da atividade que lhes compete, a definição de um meio de comunicação reclama que nós o situemos em relação ao papel que ele desempenha na organização social. Distinguir-se-á, então, aqueles dispositivos que não passaram do estágio de experiência de laboratório, e cujo valor se exprime apenas por um valor histórico, ou de evolução estritamente tecnológica, e não propriamente por sua função social.

O exemplo mais notável deste último caso é certamente o da televisão, que para além de sua dimensão técnica se tornou um verdadeiro "espaço público" de freqüentação. ${ }^{4}$ Negar estes aspectos seria certamente deixar escapar qualquer coisa de essencial, o que justamente a abordagem tecnicista não pode oferecer, pois a definição de um meio de comunicação ultrapassa o plano estritamente técnico.

\section{Plano instifucional}

Objeções similares podem ser feitas ao plano de análise da gestão institucional. Neste plano a tendência é identificar o meio de comunicação com a instituição que controla a estação transmissora. O que, em termos práticos, equivale a multiplicar o problema afirmando que existem, por exemplo, tantos Rádios quanto as instituições emissoras.

Ora, o estudo de uma emissora não é o estudo de um meio de comunicação, basta ver os trabalhos realizados seguindo esta orientação para se dar conta que estamos em presença de uma análise de métiers, de administrações e administradores, de artistas e diretores, ou simplesmente de uma análise institucional, com as idiossincrasias próprias às instituições de circulação da comunicação, claro, mas uma análise que se quer uma narrativa da história de uma certa instituição ou uma sociologia do trabalho.

Aqui, os fatos diversos do cotidiano institucional e os depoimentos pessoais vêm se misturar com os problemas da estratificação social no interior da organização, seu posicionamento político, seus engajamentos em relação à sociedade, etc.

Assim como o plano anterior, o plano institucional nos traz questões que, mesmo não sendo completamente deslocadas, nos afastam contudo das questões capitais que nos levam à definição dos meios de comunicação.

\section{Plano do usuário}

Talvez seja este o momento de lembrar que estes três planos não estão desconectados e que é mesmo possível estabelecer-se uma certa hierarquia entre eles à medida que a complexidade aumenta.

O plano tecnicista é a condição de possibilidade do plano institucional, que por sua vez é a condição de possibilidade para o plano do usuário. Dito de outro modo, os construtores de redes e de aparelhos receptores fazem seu trabalho em função das emissões a serem transmitidas, do mesmo modo que os responsáveis da indústria e do comércio de emissões fazem seu trabalho em função de um público que consumirá estas emissões e que se encontra no fim de toda essa cadeia de produção. 
Assim, um meio de comunicação complexo comporta dispositivos técnicos diversos que não têm sentido neles mesmos, mas sim em função de um objetivo único que os reúne, conferindo assim um sentido a suas atividades isoladas e a suas finalidades parciais.

Este objetivo único, para um meio como a televisão, por exemplo, não é outra coisa senão a geração do som e da imagem, ou mais precisamente do estímulo televisivo em torno do qual se reúne uma coletividade. Não se confundirá, então, - nem colocando-os sob um mesmo plano, nem designando-os por um mesmo nome - os meios que são colocados em jogo para a realização da televisão (meios técnicos e institucionais) com a televisão propriamente dita, pois esta aqui é simultaneamente o resultado da cooperação destes meios (sinergia do objeto técnico) e a finalidade que organiza o processo no seu todo, visíveis somente ao nível do usuário.

Dito de outra forma, a significação de um meio de comunicação como a televisão não pode ser estabelecida ao nível de nenhum dos setores implicados na sua produção, pois é somente ao nível de maior complexidade - aquele da telespectação, compreendendo por este termo a interface entre o dispositivo técnico e o usuário, assim como a prática social de ver televisão que se pode encontrar a significação deste meio, ou simplesmente a televisão, na medida que este termo comporta um fenômeno social.

Ao nível do usuário (telespectador) nós não encontramos mais a diversidade de segmentos que estão implicados nas condições de possibilidade da televisão (plano tecnicista e plano institucional). Nós nos encontramos em um nível sintético, que supõe os anteriores e que se exprime como uma dimensão virtual na qual mergulha a consciência individual: o telespectador não tem conta do funcionamento dos transistores, mas ele se vê "religado" a uma outra realidade gerada por um dispositivo tecnológico.
É somente nesta convergência entre a dimensão virtual, uma técnica e a expressão social da experiência que nós podemos situar o problema dos meios de comunicação, já que eles não podem ser reduzidos a nenhum de seus componentes técnicos, ou a nenhum de seus métiers, ou ainda à singularidade da experiência dos indivíduos isolados. Enfim, um meio de comunicação é a expressão social da experiência através da dimensão virtual aberta por um certo grau de simulação técnica da experiência.

Naturalmente esta demarcação do problema, ainda que seja um avanço em relação à definição instrumental (um meio de comunicação é instrumento que serve para a comunicação), não pode ter valor de definição. A nosso ver, uma definiç̧ão conceitual dos meios de comunicação deve ser buscada através do aprofundamento e da síntese das duas dimensões implicadas por estes instrumentos, ou seja, o aspecto técnico e o aspecto comunicacional.

Antes de mais nada, um meio de comunicação é uma manifestação técnica e como tal ele se dá como uma extensão do homem. O que significa dizer que os meios de comunicação reproduzem parcialmente alguma característica ou faculdade humana. Mas, admitindo-se juntamente com vários pensadores da técnica ${ }^{5}$ que todo artifício é uma extensão de um órgão, de uma função ou ainda de uma faculdade do corpo humano, se todo objeto técnico deve necessariamente guardar uma relação com o homem, nós podemos colocar a seguinte questão: qual seria a propriedade ou função do corpo humano que corresponderia aos meios de comunicação em geral? Qual propriedade do corpo humano é estendida por um meio de comunicação?

A resposta é bastante simples, trata-se naturalmente da faculdade de comunicação, como sugere a função e o nome mesmo que portam estes objetos técnicos. Sim, mas a que corresponde a comunicação em relação ao corpo humano? A resposta mais uma vez não admite nenhum equívoco, quer dizer, trata-se da consciência já que a 
comunicação é uma relação de consciências. ${ }^{6}$

Os meios de comunicação são, então, objetos técnicos que guardam uma relação bastante especial com a consciência na medida em que se manifestam como uma extensão da consciência ou, como nós preferimos dizer, como simulação da consciência.

Dessa forma nós chegamos a uma definição conceitual - os meios de comunicação são simulações da consciência - bastante simples, mas que pode abrir algumas novas perspectivas no estudo dos meios de comunicação.

\section{Téenica}

Há algum tempo venho desenvolvendo a hipótese de trabalho segundo a qual os meios de comunicação são simulações da consciência. A idéia é simples, e nasce de uma longa tradição dos estudos sobre a técnica, onde os objetos técnicos são considerados como extensões do corpo humano (exteriorizações, próteses, órgãos funcionais externos... são termos igualmente utilizados e de minha parte eu acrescento o termo simulação). Trata-se de considerar efetivamente os meios de comunicação como objetos técnicos, tirando todas as conseqüências das relações entre o corpo humano e o objeto técnico. De onde o nome de abordagem organicista, ou abordagem antropológica, dado a tal perspectiva sobre a técnica.

Pode-se dizer que sob vários aspectos nossa abordagem da técnica é uma adaptação, ao caso particular dos meios de comunicação, das teses elaboradas pelo eminente pensador francês André Leroi-Gourhan. Pai da etnologia francesa, este autor marcou profundamente os estudos sobre a técnica e suas teses podem ser acessadas com certa facilidade (nós nos baseamos sobretudo no tomo II de O Gesto e a Palavra ).

Segundo este autor, a técnica não reside no "objeto", nem é o produto direto do corpo ou do indivíduo. Ela é uma atividade que se insere num processo evolutivo e histórico, necessariamente coletivo e intimamente ligado à faculdade de simbolização. A interpretação gourhaniana da técnica vai bastante longe, pois ela indica a exteriorização como o princípio da evolução da técnica, e precisa a faculdade de simbolização como a condição desta capacidade de exteriorização. Ela também aponta o ciclo operatório como o modo através do qual esta atividade se dá, precisando assim os termos de sua composição.

Alguns dos pontos mais interessantes da abordagem gourhaniana é considerar a técnica (humana) como o produto de uma atividade simbólica (la parole) e a relação entre homem e objeto técnico como um circuito funcional (cycle opératoire).

A atividade técnica repousa sobre uma forma de raciocínio (ou racionalidade) que consiste na distinção, no isolamento e na substituição de um elemento de um dado circuito funcional (situação problema) por um elemento de outro circuito funcional (situação de apoio). Trata-se de identificar uma função, de isolar as partes materiais através das quais ela se exprime, e finalmente de substituí-la por um outro elemento que possa desenvolver uma operação similar a aquela que deve ser substituída.

A comparação se funda então sobre uma equivalência funcional, que não tem sentido senão em termos simbólicos, já que em termos absolutos não há nada de similar entre a mão e um martelo (um instrumento que estende uma função da mão).

Pode-se dizer que a racionalidade técnica é um equacionamento simbólico, um modo de perceber o "mundo », que permite substituições funcionais. Graças à representação simbólica de seu meio ambiente, e também de seu corpo, o homem torna-se capaz de substituir e de exteriorizar todos os fatores do ciclo operatório técnico (estrutura física ou instrumento, força motriz, programa de gestos, programação). Com efeito, o martelo substitui a mão enquanto estrutura de percussão (exteriorização do instrumento); a força animal e o moinho substituem os músculos humanos (exterio- 
rização da força motriz); a relojoaria e os autômatos mecânicos substituem a seqüência de gestos técnicos (exteriorização de um programa contendo vários gestos)...

A despeito do crescente grau de complexidade, a lógica é sempre a mesma, trata-se de equacionar a realidade de modo a permitir um jogo de substituições, tão simbólicas quanto reais, a fim de obter certos efeitos.

Dito de outro modo, a faculdade especificamente humana de confrontar situações é empregada pela racionalidade técnica na busca de similaridades entre elementos de sistemas físicos distintos. Se a sintaxe da racionalidade técnica se exprime através dos sintagmas de uma lógica simbólica, sua semântica, entretanto, é de ordem da matéria. De onde o valor simultaneamente simbólico e prático que ela assume.

No tocante ao domínio dos meios técnicos de comunicação, esta relação orgânica entre o objeto técnico e o corpo se dá de uma maneira bastante especial. Isto porque a atividade de comunicação estabelece uma relação de identidade entre o órgão do corpo e aquilo que é efetivamente estendido. Ou seja, todos os fatores do circuito funcional, então o órgão do corpo, o efeito que é almejado (reações afetivas), a função que é recortada da realidade (o referente enquanto símbolo) e aquela que é estendida (a linguagem), enfim todos os fatores da equação simbólica que exprimem o problema dos meios de comunicação reenviam à atividade da consciência. Codificar e decodificar uma mensagem são atos de consciência assim como a mensagem estocada sobre um suporte: ${ }^{7}$ o processo, o resultado e os elementos em jogo (signos) no circuito funcional dos meios de comunicação são invariavelmente manifestações da consciência.

Entre a mão e o martelo não há senão uma relação de analogia simbólica, relativamente arbitrária, pois é uma relação de causalidade física que proporciona sua equivalência (massa + movimento $=$ impacto, e por outro lado, mão = estrutura de impacto $=$ massa metálica). No caso dos meios de comunicação, a analogia entre a informação virtual contida num suporte material e o ato de sua decodificação se funda sobre uma continuidade ontológica, na medida em que o interpretante, assim como a "coisa" interpretada (signo) são atos de consciência. E não poderia ser de outra maneira, dado que a relação de comunicação não poderia escapar ao domínio da consciência: os meios de comunicação não poderiam reproduzir tecnicamente uma função da consciência sem estarem visceralmente ligados a ela.

Por conseguinte, o sistema funcional que religa o meio de comunicação ao utilizador não se exprime como uma simples extensão da consciência, pois, ao invés de uma analogia mais ou menos arbitrária entre os termos confrontados, trata-se de uma simulação da consciência. Os meios de comunicação não reproduzem uma função qualquer, uma função que nós distinguimos das coisas a golpes de abstração, eles simulam a própria faculdade que nós temos de representar o mundo. De onde sua particularidade dentro do universo dos objetos técnicos.

Neste sentido, os meios de comunicação são dispositivos técnicos que simulam a consciência no duplo sentido em que o produto de sua atividade é uma reprodução virtual de certos estados afetivos da consciência do emissor e no sentido que estados afetivos são simulados no traço material que carrega a mensagem e reproduzidos "pela", "na" e como consciência do receptor.

\section{Sociedade}

Com o estudo das relações entre meios de comunicação e sociedade nós atingimos o nível de maior complexidade de nosso estudo. Passagem incontornável para a compreensão do funcionamento e da razão de ser dos meios de comunicação. É também a forma de problematização mais facilmente encontrada na bibliografia consagrada aos 
meios de comunicação e, portanto, muito raramente calcada em uma teoria especializada.

Dizia-se, na antigüidade grega, que as dimensões de uma cidade deveriam ser proporcionais ao alcance da voz de um orador frente ao seu público. Mas, ao invés de aumentar o tamanho da cidade, os possantes meios de comunicação de hoje em dia virtualizaram o espaço social. O problema da antigüidade residia na maneira de tornar acessível o debate no interior da comunidade. Agora, a questão que é colocada aos nossos meios de difusão é aquela de selecionar o que deverá se tornar comum a várias comunidades, quer dizer, selecionar o que deverá se tornar propriamente social. A complexidade das ligações individuais; a alta densidade demográfica; a unificação da economia mundial, cada vez mais se consolidando como um sistema que ultrapassa as lógicas nacionais; o processo de homogeneização global da cultura (formação de uma cultura de base); o desenvolvimento dos meios de comunicação e de transporte; o turismo; os fluxos migratórios; a mestiçagem étnica... tudo isso torna muito difícil a delimitação do conceito de sociedade em um espaço preciso, a uma população específica, a um conjunto particular de costumes. $\mathrm{O}$ que o termo sociedade designa é mais uma zona de influência político-cultural que a delimitação espacial das cidades ou das nações.

A rigor, é a idéia mesma de sociedade que nasce com um novo sentido dos meios de comunicação. Há muito tempo que as pesquisas em comunicação e em sociologia convergem em direção a uma correlação forte entre Estado e meios de comunicação (H. A. Innis, Empire and Comunication, P.U. de Toronto, 1952).

As primeiras escrituras que nós conhecemos concernem à contabilidade, que teriam viabilizado o primeiro grande império, aquele da Mesopotâmia (Jack Goody, La Logique de l'Écriture: aux origines des sociétés humaines). E assim também para o palácio de Creta (J. P. Vernant, L'Origine de la pensée grecque); ou no Egito, onde a escrita veio regular a divisão de terras após as baixas do Nilo (James Février, Histoire de l'écriture). Para além de toda controvérsia, os trabalhos citados corroboram a afirmação de que a organização do Estado não poderia ser viabilizada sem a assistência de possantes dispositivos de comunicação.

Se a relação entre escrita e Estado parece consolidada, entretanto devemos precisá-la. De uma parte, é preciso dizer que a noção de império designa um conjunto de territórios governados por uma autoridade única e não uma unidade cultural. De outra parte, é preciso ter em conta que os meios de comunicação não desempenhavam senão um papel restrito: burocracia, contabilidade do palácio, administração do império através de despachos concernentes aos negócios estatais enviados a centros afastados, informações e instruções militares.

Eis aqui a dimensão da ação dos meios de comunicação, à qual se pode acrescentar os textos sagrados de certas religiões que se serviam da escrita como de um saber religioso. Todos estes elementos vêm testemunhar que na antigüidade os meios de comunicação se inscrevem no uso das classes dirigentes, reforçando a idéia que eles tinham um alcance funcional reduzido.

Estas observações nos mostram que os meios de comunicação não atuavam diretamente na dinâmica da coletividade, eles não estavam presentes no cotidiano da vida dos indivíduos: não se colocava a questão de se servir deles para difundir uma "informação" (a mensagem sagrada ou militar é da ordem do confidencial), nem para fazer conhecer suas idéias ou seus sentimentos a seus semelhantes: os meios de comunicação não participavam das relações interpessoais. De fato, a vida em comunidade dispensa o uso de meios de comunicação, já que por definição a idéia de comunidade implica justamente a companhia efetiva dos outros membros: por que se servir de um telefone, de uma carta, de um rádio... para se dirigir a aqueles que estão perto, aqueles que compar- 
tem o cotidiano conosco?

O contraste com nossas sociedades atuais é flagrante. Ainda mais se levarmos em conta que, ao contrário da vida nas comunidades primitivas, o indivíduo moderno não tem sua pertença ao grupo garantida pelos vínculos de sangue ou pela tradição.

Agora, é a vontade dos participantes de fazer parte da comunidade e de participar das responsabilidade que é o fator constitutivo das novas sociedades. A velha sociedade, fundada sobre a responsabilidade coletiva, é substituída por um novo princípio de sociedade, um princípio racional porque reflete a vontade do indivíduo que consente em engajar determinados meios em vista de um fim preciso (F. Jonas, citando Histoire de la Sociologie, de M. Weber, in Larousse, 1991, p. 357).

Dessa forma, os meios de comunicação aparecem sob dois ângulos diferentes. Primeiro ao nível do fundamento de nossa organização social, como um dos vetores que viabilizam a vida para além do espaço comunitário. Note-se, a propósito, que a comunidade não deixa de existir na modernidade, mas que ganha um novo sentido na medida em que o indivíduo moderno constrói sua identidade a partir do pertencimento a várias comunidades. ${ }^{8}$ Os meios de comunicação aparecem então como uma dimensão virtual, um espaço público, transcomunitário, que permite a geração de valores e representações comuns a todas as comunidades. Esta dimensão virtual aberta na vida das comunidades permite não somente a geração de uma cultura para todos (cultura de massa), mas também a geração de um tempo de atualidade, que se manifesta como um cotidiano compartilhado pelo conjunto das comunidades.

De outro lado, ao nível dos agentes sociais, os meios de comunicação também podem ser compreendidos como os instrumentos dos quais os indivíduos lançam mão para ter uma representação e para sondar o espaço social, exercendo assim sua vontade e suas estratégias racionais de integração. É a partir das informações reco- lhidas de sua freqüentação dos meios que o indivíduo toma conhecimento das atividades da vida coletiva ao nível social; é a partir dessas informações que ele elabora uma representação de fatos e acontecimentos que não estão diretamente ao seu alcance, mas aos quais, de uma forma ou de outra, ele se sente ligado

\section{Notas}

1 LASSWELL, D. H. "A Estrutura e a Função da Comunicação na Sociedade", in COHN, Gabriel, Comunicação e Indústria Cultural. E. Nacional/Edusp. S. Paulo, 1971, pp. 105-117.

2 Em realidade, para as finalidades da presente exposição, pouca diferença faz se utilizarmos os trabalhos de Jensen e Rosengrend, de Mauro Wolf ou de Elihu Katz.

3 Em uma interessante palestra no XXIII Congresso da INTERCOM, Sociedade Brasileira de Estudos Interdisciplinares da Comunicação, realizado em Manaus, em setembro de 2000, Elihu Katz mostrava-se relutante em classificar os estudos culturais como uma tradição de pesquisa em comunicação. Não exatamente porque faltam publicações ou estudos nesta área, mas porque não se pode discernir uma unidade nestes estudos de forma a estruturar uma corrente de pesquisa. Os estudos de meios, além de terem um volume muito menor de publicações específicas, também apresentam um problema semelhante. Os poucos estudos normalmente classificados nesta rubrica (Innis, McLuhan, Goody, E. Eisenstein, Deutch, etc.) não têm uma perspectiva comum, nem trabalham o meio de forma central. Eles são adaptações de outros problemas, normalmente vindos de outra área (história, sociologia, antropologia...). Razão pela qual estes estudos são muito raramente classificados dessa forma pelos teóricos quando de um panorama das tradições de pesquisa.

4 Esta distinção é bastante importante, e nem por isso é levada em conta nas análises de meios. Não é raro encontrarmos um nivelamento entre meios de diferentes expressões sociais, tais como a televisão e a Internet. Enquanto a primeira se encontra em praticamente todos os lares da sociedade brasileira, apenas $3 \%$ da população mundial utilizam a Internet. 
5 Entre outros, Lewis Mumford, André Leroi-Gourhan, Ives Goffy, Henri Bergson, Paul Virilio, M. McLuhan... Para uma crítica aprofundada da analogia com o corpo humano implícita na noção de extensão e para uma análise da variedade de conceitos (prótese, exteriorização, sistema funcional, simulação), ver MARTINO, Luiz C., "Télévision et Conscience", Tese de Doutorado em sociologia, Sorbonne Paris V, 1997.

6 Sobre a comunicação como relação de consciências ver Eliane AMADO LEVY-VALENSI, La Communication. PUF, 1967 e Jacques DURAND, Les Formes de la Communication. Dunod/Bordas. Paris, 1981.

7 Cf. RUYER, Raymond, La Cybernétique et l'Origine de l'Information. Flammarion, 1968.

8 Cf. Stuart HALL, Identidades culturais na pós-modernidade. DP\&A Editora, Rio de Janeiro, 1997.

\section{Referências}

AMADO LEVY-VALENSI, Eliane, La Communication. PUF, 1967.

DURAND, Jacques, Les Formes de la Communication. Dunod/ Bordas. Paris, 1981.

JENSEN, Klaus, BRUHN et ROSENGREN, Karl Erik, "Cinq traditions à la Recherche du Public", Revue Hermès, no 1112, numéro spécial. CNRS Editions. Paris, 1993 (Version originelle: European Journal of Communications, SAGE, London, Vol. 5, 1990).

KATZ, E. "A propos des médias et de leurs effets", in SFEZ, L. (org.) Technologies et Symboliques de la Communication. Colloque de Ceresy 1988 Press Universitaire de Grenoble, 1990, pp. 275-282 (Tradução para o português de L.C. Martino, mecanografado, Brasília, 1999).

LEROI-GOURHAN, André, Le Geste et la Parole : la mémoire et les rythmes. Albin Michel. Paris, 1991.

MARTINO, Luiz C., "Télévision et Conscience". Tese de Doutorado. UFR de Sciences Sociales, Université Réné Descartes, Sorbonne Paris-V. Paris, junho de 1997.

MATTELART, Armand, História das Teorias da Comunicação.
Loyola. São Paulo.

WOLF, Mauro, Teorias da Comunicação. Presença. Lisboa, 1995. 